\title{
Anti-c-MET Monoclonal Antibody LY2875358
}

National Cancer Institute

\section{Source}

National Cancer Institute. Anti-c-MET Monoclonal Antibody LY2875358. NCI Thesaurus.

Code $C 95732$.

A humanized IgG4 monoclonal antibody directed against human hepatocyte growth factor receptor (HGFR or c-MET) with potential antineoplastic activity. Anti-c-MET monoclonal antibody LY2875358 binds to c-MET, thereby preventing the binding of HGF to its receptor c-Met and subsequent activation of the HGF/c-Met signaling pathway. This may result in cell death in c-Met-expressing tumor cells. c-Met, a receptor tyrosine kinase overexpressed or mutated in many tumor cell types, plays a key role in cancer cell growth, survival, angiogenesis, invasion, and metastasis. 